\title{
PERBANDINGAN FINANCIAL DISTRESS BANK SYARIAH DI INDONESIA DAN BANK ISLAM DI MALAYSIA SEBELUM DAN SESUDAH KRISIS GLOBAL 2008 MENGGUNAKAN MODEL ALTMAN Z- SCORE 11
}

\author{
Siti Zulaikah \\ Program Studi S1 Ekonomi Islam-Fakultas Ekonomi dan Bisnis-Universitas Airlangga \\ Email : laykajula@gmail.com \\ Nisful Laila \\ Departemen Ekonomi Syariah- Fakultas Ekonomi dan Bisnis-Universitas Airlangga \\ Email : nisful.laila@gmail.com
}

\begin{abstract}
:
This study aims to find out the comparison between the prediction of financial distress of Islamic Banks in Indonesia and that of Islamic Banks in Malaysia before and after the global crisis 2008 using quantitative method and purposive sampling. The prediction of financial distress was done by using Altman Z-score measuring. The technique used to examine the financial distress is Mann-Whitney, and for those after the crisis were examined using Independent sample T-test. The result of this research shows that there is a significant difference between Islamic banks in Indonesia and those in Malaysia either before or after the global crisis 2008 with 5\% significance level. The Islamic banks in Indonesia are in secure zone either before or after the crisis. However, the Islamic banks in Malaysia are in grey area which cannot be made sure of the bankruptcy either before or after the crisis.
\end{abstract}

Keywords : Financial Distress, Islamic Bank, Global Crisis, Altman Z-Score

\section{PENDAHULUAN}

Krisis global yang terjadi pada tahun 2008 disebabkan oleh subprime mortage. Subprime mortage adalah kredit perumahan (mortage) yang diberikan kepada debitur dengan sejarah kredit yang buruk atau belum memiliki sejarah kredit sama sekali sehingga digolongkan kredit dengan risiko yang tinggi (BI, 2009). Subprime mortage dari AS menandai mulainya krisis dengan cepat meluas menjadi krisis likuiditas terburuk di berbagai belahan dunia (Mishkin, 2010). Selanjutnya, terdapat beberapa kegagalan bank dunia seperti bank Anglo Irish, Lehman Brothers, dan Citigroup New York yang sangat mempengaruhi aliran keuangan global (Sharma, 2013). Dampak

krisis global tersebut menyerang pada perekonomian suatu negara terutama sektor perbankan karena berdasarkan Moechidi dkk (2012) sekitar $80 \%$ pendanaan usaha adalah berasal dari sektor perbankan. Dampak krisis yang dihadapi negara-negara tersebut pada umumnya adalah meningkatnya inflasi, turunnya nilai tukar, turunnya pertumbuhan ekonomi, runtuhnya indeks bursa dan sejumlah bank/institusi keuangan/korporasi mengalami kesulitan keuangan atau bangkrut (Sudarsono, 2009).Krisis global 2008 tersebut berdampak pada banyak negara terutama negara yang sedang berkembang. Bukan hanya Indonesia,

\footnotetext{
1) Jurnal ini merupakan bagian dari skripsi dari Siti Zulaikah, NIM : 041211431158 , yang diuji pada 2 Mei 2016.
} 
Zulaikah, et al/Jurnal Ekonomi Syariah Teori dan Terapan Vol. 3 No. 11 November 2016: 900-914; PERBANDINGAN FINANCIAL DISTRESS BANK SYARIAH DI INDONESIA DAN BANK ISLAM DI MALAYSIA SEBELUM DAN SESUDAH KRISIS GLOBAL 2008 MENGGUNAKAN MODEL ALTMAN Z-SCORE

salah satunya adalah negara Malaysia yang merupakan pertama kali mendirikan bank syariah di Asia Tenggara. Bank Islam Malaysia Berhad (BIMB) merupakan bank syariah pertama di Asia Tenggara (Antonio, 2001 : 24). Ekonomi Malaysia mencatat pertumbuhan sebesar $4,6 \%$ pada awal tahun 2008. Namun pada akhir tahun 2008 pertumbuhan ekonomi mulai mengalami perlambatan dan hanya meningkat $0,1 \%$. Kemudian Malaysia kembali mengalami penurunan sebesar 1,6\% pada tahun 2009 (Awang, Tanpa Tahun). Sama halnya dengan Indonesia, bank Islam di Malaysia mampu lebih unggul dibandingkan dengan bank konvensional dengan modal pasar secara gabungan hanya menurun $8,5 \%$, keuntungan bersih menurun 9,25\%, peningkatan aset $55 \%$, peningkatan ekuitas $36 \%$ dan rasio leverage 6,6 kali (IFSB-IRTI-IDB Ilamic Finance and Global Financial Stability Report, 2010).

Negara Malaysia merupakan negara pertama pendiri bank syariah di Asia Tenggara yang dapat dijadikan sebagai pedoman untuk perkembangan bank-bank syariah di negara lainnya. Pendirian bank syariah di Indonesia tertinggal 8 tahun lebih lambat diabndingankan pendirian bank Islam di Malaysia. Peneliti tertarik untuk melakukan perbandingan bank syariah di Indonesia dan bank Islam Malaysia untuk melihat seberapa jauh kinerja bank syariah di Indonesia jika dibandingkan dengan kinerja bank Islam di Malaysia. Adapun data perbandingan aset antara bank syariah di Indonesia dan bank Islam di Malaysia sebagai berikut.

Sumber : Otoritas Jasa Keuangan. 2008.

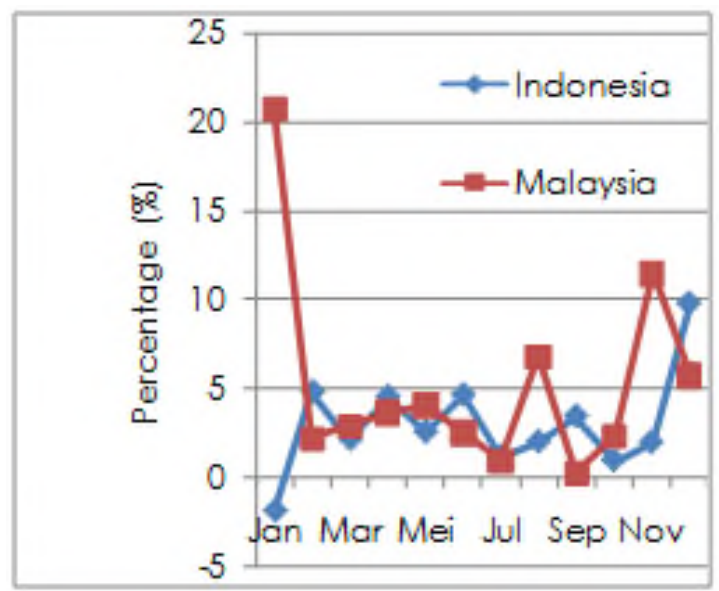

Statistik Perbankan Indonesia 2008, (Online), (http://ojk.co.id, diakses 10 Januari 2016) dan Bank Negara Malaysia. 2008. Islamic Banking System : Statement of Assets. (Online), (http://bnm.co.id, dikases 15 Desember 2015)

\section{Gambar 1.}

\section{Perkembangan Aset Bank Syariah di} Indonesia dan Malaysia

Gambar 1. menunjukkan bahwa perbandingan perkembangan aset bank syariah di Indonesia dan bank Islam di Malaysia tidak stabil ketika terjadi krisis global. Kondisi tidak stabil dari perkembangan aset bank syariah tersebut merupakan salah satu dampak negatif adanya krisis global 2008 yang harus diperhatikan oleh bank syariah untuk tahun-tahun berikutnya.

Urgency dilakukannya penelitian tentang financial distress adalah dikarenakan perbankan menjadi sektor utama dalam pendanaan usaha di suatu negara. Pasang surut dalam dunia bisnis tidak membuat perjalanan bisnis sebuah 
Zulaikah, et al/Jurnal Ekonomi Syariah Teori dan Terapan Vol. 3 No. 11 November 2016: 900-914; PERBANDINGAN FINANCIAL DISTRESS BANK SYARIAH DI INDONESIA DAN BANK ISLAM DI MALAYSIA SEBELUM DAN SESUDAH KRISIS GLOBAL 2008 MENGGUNAKAN MODEL ALTMAN Z-SCORE

perusahaan selalu menunjukkan perkembangan usaha tetapi pada suatu waktu ada saatnya mengalami kesulitan keuangan yang berat (Husnan, 1985 : 171). Perusahaan dikatakan mengalami kondisi financial distress yaitu ketika perusahaan tersebut tidak mempunyai kemampuan untuk memenuhi pembayaran hutangnya kepada kreditur ketika jatuh tempo (Emery dan Finnety, 1997).

Kebangkrutan dapat memberikan dampak buruk salah satunya yaitu terjadinya putus hubungan kerja. Pemutusan hubungan kerja tersebut menjadikan jumlah pengangguran dan kemiskinan semakin meningkat. Maka dari itu bank syariah harus mampu menjaga kestabilan keuangan untuk menghindari kemiskinan sebagaimana Islam tidak menyukai kemiskinan untuk menghindari kekufuran. Hal tersebut sesuai dengan AlQuran surat Al Baqarah ayat 268 yaitu :

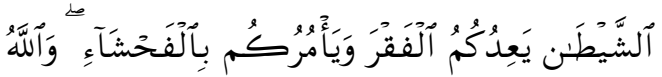

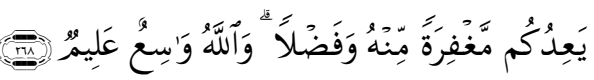

Artinhya : Syaitan menjanjikan (menakut-nakuti) kamu dengan kemiskinan dan menyuruh kamu berbuat kejahatan (kikir), sedang Allah menjadikan untukmu ampunan daripada-Nya dan karunia. Dan Allah Maha Luas (karunia-Nya) lagi Maha Mengatahui.

$$
\text { Selain itu, Ekowanti (2011) }
$$
menyatakan bahwa terdapat perbedaan kinerja keuangan secara signifikan maupun rata-rata antara Bank Muamalat Indonesia, Bank Syariah Mandiri dan Bank
Mega Syariah sebelum dan sesudah terjadinya krisis global 2008.

Hasil penelitian yang telah dilakukan oleh berbagai peneliti dan di berbagai negara tentang kinerja perbankan syariah yang berbeda-beda menarik perhatian dan topik untuk dikaji jika dibandingkan antar negara satu dengan negara yang lainnya. Penelitian yang dilakukan akan memperlihatkan bagaimana ketahanan bank syariah di negara yang berbeda, yaitu Indonesia dan Malaysia.

Berdasarkan latar belakang yang telah dipaparkan diatas, maka dapat diambil rumusan masalah pada penelitian ini, yaitu adakah perbedaan yang signifikan atas prediksi financial distress bank syariah di Indonesia dan bank Islam di Malaysia sebelum dan sesudah krisis global 2008?

Adapun tujuan penelitian ini adalah meneliti dan mendapatkan bukti empiris perbandingan prediksi financial distress bank syariah di Indonesia dan bank Islam di Malaysia sebelum dan sesudah krisis global 2008.

\section{LANDASAN TEORI}

Financial distress merupakan sebagai tahap penurunan kondisi kevangan yang terjadi sebelum terjadinya kebangkrutan ataupun likuidasi (Plat dan Plat, 2002). Rasio hutang yang tinggi akan meningkatkan ancaman kebangkrutan. Pertama, semakin tinggi rasio hutang, maka perusahaan tersebut akan semakin berisiko, sehingga semakin tinggi pula 
Zulaikah, et al/Jurnal Ekonomi Syariah Teori dan Terapan Vol. 3 No. 11 November 2016: 900-914; PERBANDINGAN FINANCIAL DISTRESS BANK SYARIAH DI INDONESIA DAN BANK ISLAM DI MALAYSIA SEBELUM DAN SESUDAH KRISIS GLOBAL 2008 MENGGUNAKAN MODEL ALTMAN Z-SCORE

biaya dari baik hutang maupun ekuitasnya. Kedua, jika sebuah perusahaan mengalami masa-masa sulit dan laba operasi tidak cukup untuk menutupi beban bunga, para pemegang sahamnya harus menutupi kekurangan tersebut, dan jika mereka tidak dapat melakukannya, maka akan terjadi kebangkrutan (Brigham dan Houston, 2006). Financial distress yang terjadi pada sebuah perusahaan disebabkan oleh beberapa faktor, baik internal maupun eksternal (Munawir, 2002 : 289). Apabila ditinjau dari sisi keuangan perusahaan (financial factor) maka terdapat tiga keadaan yang dapat menyebabkan financial distress bisa terjadi, yaitu:

1. Faktor Ketidakmampuan Modal atau Kekurangan Dana.

2. Besarnya Beban Hutang dan Bunga.

3. Menderita Kerugian.

Banyak perusahaan yang mengalami financial distress, dimana masalah intinya adalah manajemen yang buruk (Altman \& Hotchkiss, 2006).

Model yang biasanya digunakan dalam prediksi financial distress adalah Altman Z-score, CAMEL dan Bankometer . Pada penelitian yang telah dilakukan oleh Erari (2013) menunjukkan perbandingan antara model CAMEL(S), Z-Score dan Bankometer serta menyatakan bahwa Bankometer dan Z-Score relatif mudah digunakan dengan tingkat akurasi yang tinggi. Penelitian yang dilakukan oleh Kristanti (2014) mengatakan bahwa Bankometer memiliki beberapa kelemahan jika digunakan untuk memprediksi financial distress, yaitu :

1. Model ini belum banyak dikenal dan belum diakui sebagai analisis yang valid untuk prediksi financial distress bagi bank.

2. Model ini belum diuji secara luas, terutama dalam hal membandingkan hasil prediksi financial distress sebuah bank.

Pada tahun 1968, Altman menerapkan Multiple Discriminant Analysis untuk pertama kalinya. Analisis diskriminan yang dilakukan Altman dengan mengidentifikasikan rasio-rasio keuangan menghasilkan suatu model yang dapat memprediksi perusahaan yang memiliki kemungkinan tinggi untuk bangkrut dan tidak bangkrut (Prihanthini \& Sari, 2013). Penggunaan model Altman sebagai salah satu pengukuran kinerja kebangkrutan tidak bersifat tetap atau stagnan melainkan berkembang dari waktu kewaktu, dimana pengujian dan penemuan model terus diperluas oleh Altman hingga penerapannya tidak hanya pada perusahaan manufaktur publik saja tetapi sudah mencakup perusahaan manufaktur nonpublik, perusahaan nonmanufaktur, dan perusahaan obligasi korporasi (Ramadhani \& Lukviarman, 2009). Analisis Z-score yang pertama kali dikembangkan oleh Altman pada 1968 tersebut dinilai kurang relevan dengan kekurangan antara lain dari model ini tidak dapat mutlak digunakan karena ada kalanya 
Zulaikah, et al/Jurnal Ekonomi Syariah Teori dan Terapan Vol. 3 No. 11 November 2016: 900-914; PERBANDINGAN FINANCIAL DISTRESS BANK SYARIAH DI INDONESIA DAN BANK ISLAM DI MALAYSIA SEBELUM DAN SESUDAH KRISIS GLOBAL 2008 MENGGUNAKAN MODEL ALTMAN Z-SCORE

terdapat hasil yang berbeda jika kita menggunakan obyek penelitian yang berbeda ( Endri, 2009). Maka dari itu Altman kembali memodifikasi formula Zscorenya pada tahun 1995 dengan mengubah indikator market value of equity menjadi book value of equity to total liability. Altman melakukan revisian supaya dapat diterapkan pada semua perusahaan seperti manufaktur, nonmanufaktur, dan perusahaan penerbit obligasi di negara berkembang (emerging market) (Nugroho, 2012). Berikut persamaan Z-Score yang di modifikasi (Altman dkk, 1995) :

$Z^{\prime \prime}=6,56 X 1+3,26 X 2+6,72 \times 3+1,05 X 4 \ldots .(1)$

Z" = Bankruptcy

$X 1=$ Working Capital to Total Asset

$X 2=$ Retained Earning to Total Asset

X3 $=$ Earning Before Interest and Taxes to

Total Asset

X4 = Book value of Equity to Total Liability

Kelebihan dari analisis Z-score ini adalah bahwa dengan mengetahui nilai z perusahaan dengan metode diskriminan kebangkrutan Altman maka perusahaan dapat mengetahui tingkat kesehatan keuangan perusahaannya, maka perusahaan masih bisa memperbaiki kesehatan keuangan perusahaannya dengan segera. Sehingga dengan mengetahui nilai $\mathrm{z}$ ini maka kondisi keuangan perusahaan akan semakin kuat dan dapat diantisipasi sedini mungkin (early warning system) sebelum kinerja dan kesehatan keuangan perusahaan dipengaruhi oleh beberapa indikator-indikator kegagalan keuangan perusahaan. Selain itu kelebihan yang lainnya adalah bahwa model perhitungan diskriminan (Altman) ini juga bisa diterapkan untuk perusahaan perusahaan yang go public atau tidak go public (Hanafi, 2005).

\section{METODE PENELITIAN}

\section{Definisi Operasional}

Agar variabel yang digunakan dalam penelitian ini dapat diukur, serta untuk menghindari adanya kesalahpahaman dan penafsiran makna yang berbeda, maka variabel dalam penelitian ini harus diberi definisi. Adapun definisi dari variabel-variabel yang digunakan dalam penelitian ini adalah :

1. Working Capital to Total Asset. Working capital to total asset merupakan indikator untuk mengukur besarnya aset likuid apabila dibandingkan dengan keseluruhan aset yang dimiliki. Rasio ini menunjukkan kemampuan perusahaan untuk menghasilkan modal kerja bersih dari keseluruhan aktiva yang dimilikinya. Working capital to total asset merupakan selisih dari current asset dan current liabilities. Rumusnya adalah sebagai berikut :

WCTA = Working Capital / Total Asset....(2)

2. Retained Earning to Total Asset. Rasio ini merupakan indikator untuk mengukur kemampuan perusahaan dalam mengahsilkan laba ditahan dari total aktiva yang dimiliki oleh perusahaan (Nugroho, 2012). Rumusnya adalah sebagai berikut : 
Zulaikah, et al/Jurnal Ekonomi Syariah Teori dan Terapan Vol. 3 No. 11 November 2016: 900-914; PERBANDINGAN FINANCIAL DISTRESS BANK SYARIAH DI INDONESIA DAN BANK ISLAM DI MALAYSIA SEBELUM DAN SESUDAH KRISIS GLOBAL 2008 MENGGUNAKAN MODEL ALTMAN Z-SCORE

RETA = Retained Earning / Total Asset....(3)

3. Earning Before Interest and Taxes to Total Asset. Rasio ini merupakan indikator untuk mengukur kemampuan dari modal yang diinvestasikan dalam keseluruhan aktiva untuk menghasilkan keuntungan bagi semua investor termasuk pemegang saham dan obligasi (Riyanto, 1995). Hasilnya akan menunjukkan kemampuan perusahaan untuk menghasilkan laba dari aktiva perusahaan sebelum pembayaran bunga dan pajak. Rumusnya adalah sebagai berikut :

$\mathrm{EBITTA}=$ Earning Before Interest and Taxes / Total Asset.

4. Book Value of Equity to Total of Liability. Rasio ini merupakan indikator untuk mengukur tingkat leverage dari suatu perusahaan. Rasio yang digunakan untuk mengukur sejauh mana aktiva perusahaan dibiayai dari hutang (Nugroho, 2012). Hutang yang terlampau besar akan berbahaya bagi kelangsungan perusahaan, terutama jika terdapat bunga yang harus dibayar. Rumusnya adalah sebagai berikut :

BVETTL $=$ Book Value of Equity / Total Liability.....

5. Z-Score. Altman memodifikasi formula ZScorenya pada tahun 1995 dengan mengubah indikator market value of equity menjadi book value of equity to total liability. Berikut persamaan Z-Score yang di modifikasi (Altman dkk, 1995) : $\left.Z^{\prime \prime}=6,56 \times 1+3,26 \times 2+6,72 \times 3+1,05 \times 4 \ldots .6\right)$
$Z$ " = Bankruptcy

$X 1=$ Working Capital to Total Asset

$X 2=$ Retained Earning to Total Asset

$X 3=$ Earning Before Interest and Taxes to Total Asset

X4 = Book Value of Equity to Total Liability

Klasifikasi perusahaan yang sehat dan bangkrut didasarkan pada nilai ZScore model Altman Modifikasi yaitu:

a. Jika nilai $Z "<1,1$ termasuk perusahaan yang bangkrut.

b. Jika nilai 1,1 < Z" < 2,6 termasuk grey area (tidak dapat ditentukan apakah perusahaan sehat ataupun mengalami kebangkrutan).

c. Jika nilai Z" > 2,6 termasuk perusahaan yang tidak bangkrut.

\section{Jenis dan Sumber Data}

Jenis data yang digunakan dalam penelitian ini adalah data sekunder. Data sekunder adalah data yang diperoleh dari suatu organisasi atau perusahaan dalam bentuk yang sudah jadi berupa publikasi (Supranto, 2009 : 112). Penelitian ini menggunakan data panel karena mengumpulkan data dari berbagai bank syariah di Indonesia dan bank Islam di Malaysia untuk periode tahun 2006, 2007, 2009, dan 2010 agar dapat dibandingkan financial distress bank di kedua negara tersebut tersebut. Data dapat diperoleh dari laporan tahunan atau annual report dari bank yang bersangkutan.

\section{Populasi dan Sampel}

Pada penelitian ini populasinya adalah bank syariah yang ada di Indonesia dan di Malaysia. Teknik 
Zulaikah, et al/Jurnal Ekonomi Syariah Teori dan Terapan Vol. 3 No. 11 November 2016: 900-914; PERBANDINGAN FINANCIAL DISTRESS BANK SYARIAH DI INDONESIA DAN BANK ISLAM DI MALAYSIA SEBELUM DAN SESUDAH KRISIS GLOBAL 2008 MENGGUNAKAN MODEL ALTMAN Z-SCORE

pengambilan sampel yang digunakan adalah purposive sampling. Purposive sampling adalah teknik penentuan sampel dengan pertimbangan tertentu (Anshori dan Iswati, 2009 : 105). Kriteria dalam pengambilan sampel pada penelitian ini adalah sebagai berikut :

1. Bank syariah yang ada di Indonesia dan bank Islam di Malaysia.

2. Bank dengan status kepemilikan lokal.

3. Bank syariah yang didirikan atau lahir sebelum tahun 2008.

4. Bank syariah yang memiliki annual report tahun 2006, 2007, 2009 dan 2010 berakhir 31 Desember.

Tabel 1.

Sampel Bank

\begin{tabular}{|l|l|}
\hline \multicolumn{1}{|c|}{$\begin{array}{c}\text { Bank Syariah } \\
\text { Indonesia }\end{array}$} & \multicolumn{1}{c|}{$\begin{array}{c}\text { Bank Islam } \\
\text { Malaysia }\end{array}$} \\
\hline $\begin{array}{l}\text { Bank Muamalat } \\
\text { Indonesia }\end{array}$ & $\begin{array}{l}\text { Affin Islamic Bank } \\
\text { Berhad }\end{array}$ \\
\hline $\begin{array}{l}\text { Banks Syariah } \\
\text { Mandiri }\end{array}$ & $\begin{array}{l}\text { Bank Muamalat } \\
\text { Malaysia Berhad }\end{array}$ \\
\hline $\begin{array}{l}\text { Bank Mega } \\
\text { Syariah }\end{array}$ & $\begin{array}{l}\text { CIMB Islamic Bank } \\
\text { Berhad }\end{array}$ \\
\hline & $\begin{array}{l}\text { RHB Islamic Bank } \\
\text { Berhad }\end{array}$ \\
\hline Sumber : Otoritas Jasa Keuangan dan \\
\multicolumn{3}{|l}{ Bank Negara Malaysia } \\
\hline
\end{tabular}

Teknik Analisis Data

Proses pengujian hipotesis yang dirumuskan yaitu perbandingan nilai ZScore pada financial distress keuangan bank syariah di Indonesia dan bank Islam di Malaysia sebelum dan sesudah krisis global 2008, maka dilakukan analisis sebagai berikut :

1. Menghitung nilai rasio Working Capital to Total Asset, Retained Earning to Total Asset, Earning Before Interest and Taxes to Total Asset, dan Book Value of Equity to Total Liability pada masing-masing bank syariah di Indonesia dan bank Islam di Malaysia.

2. Menghitung nilai Z-Score pada masingmasing bank syariah di Indonesia dan bank Islam di Malaysia.

3. Uji normalitas, merupakan syarat utama yang harus dilakukan untuk mengetahui apakah data terdistribusi normal atau tidak terdistribusi normal. Metode yang digunakan untuk menguji normalitas data pada penelitian ini adalah uji KolmogorovSmirnov. Jika terdistribusi normal maka menggunakan independent sample $T$ test. Sedangkan jika data tidak terdistribusi normal maka menggunakan uji Mann-Whitney.

4. Uji homogenitas varian (Levene Test). Uji ini berfungsi untuk menguji apakah dua sampel yang diambil dalam penelitian memiliki varians yang sama (Santoso, $203: 3)$.

5. Uji hipotesis. Pada pengujian ini hipotesis yang diangkat adalah $\mathrm{HO}: \mathrm{X} 1$ $=\mathrm{X} 2$ (tidak ada perbedaan yang signifikan antara rata-rata nilai Z-Score pada bank syariah di Indonesia dan bank Islam di Malaysia). Sedangkan hipotesis alternatifnya adalah $\mathrm{H} 1: \mathrm{X} 1 \neq$ $X 2$ (terdapat perbedaan yang signifikan antara rata-rata nilai Z-Score pada bank syariah di Indonesia dan bank Islam di Malaysia).

6. Menentukan tingkat signifikansi. Tahap ini menentukan seberapa besar 
Zulaikah, et al/Jurnal Ekonomi Syariah Teori dan Terapan Vol. 3 No. 11 November 2016: 900-914; PERBANDINGAN FINANCIAL DISTRESS BANK SYARIAH DI INDONESIA DAN BANK ISLAM DI MALAYSIA SEBELUM DAN SESUDAH KRISIS GLOBAL 2008 MENGGUNAKAN MODEL ALTMAN Z-SCORE

peluang membuat risiko kesalahan dalam mengambil keputusan menolak hipotesis yang benar. Tingkat signifikansi dalam penelitian ini adalah $a=5 \%$.

7. Menarik keputusan.

\section{HASIL DAN PEMBAHASAN Uji Normalitas}

Uji normalitas adalah uji yang dilakukan untuk melihat apakah kumpulan data terdistribusi normal atau tidak terdistribusi normal. Metode yang digunakan untuk menguji normalitas data pada penelitian ini adalah uji KolmogorovSmirnov. Jika terdistribusi secara normal maka menggunakan independent sample $T$ test. Sedangkan jika dat tidak terdistribusi normal maka menggunakan uji Mann-Whitney.

Tabel 2.

Hasil Uji Normalitas Kolmogorov-Smirnov Test

\begin{tabular}{|l|c|c|c|}
\hline & Subjek & Sig. & Hasil \\
\hline $\begin{array}{l}\text { Sebelum } \\
\text { Krisis }\end{array}$ & Indonesia & 0,200 & $\begin{array}{c}\text { Distribusi } \\
\text { normal }\end{array}$ \\
\cline { 2 - 4 } & Malaysia & 0,004 & $\begin{array}{c}\text { Tidak } \\
\text { terdistrib } \\
\text { Usi } \\
\text { normal }\end{array}$ \\
\hline $\begin{array}{l}\text { Sesudah } \\
\text { Krisis }\end{array}$ & Indonesia & 0,200 & $\begin{array}{c}\text { Distribusi } \\
\text { normal }\end{array}$ \\
\cline { 2 - 4 } & Malaysia & 0,024 & $\begin{array}{c}\text { Tidak } \\
\text { terdistrib } \\
\text { Usi } \\
\text { normal }\end{array}$ \\
\hline
\end{tabular}

Sumber : Hasil Penelitian, 2016 (diolah)

Tabel 2. menunjukkan nilai signifikansi sebelum krisis Indonesia 0,200 > 0,05 dan Malaysia 0,004 $<0,05$. Sebelum krisis dinyatakan tidak terdistribusi normal karena tingkat signifikansi yang kurang dari 0,05 . Sedangkan nilai signifikansi sesudah krisis Indonesia 0,200 > 0,05 dan
Malaysia $0,024<0,05$. Nilai signifikansi sesudah krisis memiliki nilai yang kurang dari 0,05 , maka data tersebut dinyatakan tidak terdistribusi normal. Kesimpulan hasil uji normalitas menyatakan bahwa pengujian hipotesis sebelum dan sesudah krisis menggunakan Mann-Whitney.

\section{Uji Homogenitas}

Uji homogenitas varian (Levene Test). Uji ini berfungsi untuk menguji apakah dua sampel yang diambil dalam penelitian memiliki varians yang sama (Santoso, 203 : 3). Uji ini dilakukan untuk memastikan bahwa perbedaan yang mungkin terjadi dalam hipotesis merupakan perbedaan antara kelompok dan bukan merupakan akibat dari perbedaan yang terjadi di dalam kelompok data sampel. Apabila sig. > 0,05 maka varian sama. Sedangkan apabila sig. $<0,05$ maka varian berbeda.

\section{Tabel 3.}

Uji Homogenitas Varian Data Nilai Z-Score

\begin{tabular}{|l|c|l|l|}
\hline & $\begin{array}{c}\text { Levene's } \\
\text { Test of } \\
\text { Equality } \\
\text { of } \\
\text { Variance }\end{array}$ & $\begin{array}{c}\text { Kaidah } \\
\text { Pengujian }\end{array}$ & Hasil \\
\hline $\begin{array}{l}\text { Sebelum } \\
\text { Krisis }\end{array}$ & 0,865 & $\begin{array}{l}\mathrm{P} \text { value }> \\
0,05\end{array}$ & $\begin{array}{l}\text { Kedua } \\
\text { Varian } \\
\text { Sama }\end{array}$ \\
\hline $\begin{array}{l}\text { Sesudah } \\
\text { Krisis }\end{array}$ & 0,029 & $\begin{array}{l}\mathrm{P} \text { value }< \\
0,05\end{array}$ & $\begin{array}{l}\text { Kedua } \\
\text { Varian } \\
\text { Berbe } \\
\text { da }\end{array}$ \\
\hline
\end{tabular}

Sumber : Hasil Penelitian, 2016 (diolah)

Tabel 3. menunjukkan bahwa nilai signifikansi levene's test of equality of variance sebelum krisis 0,865 > 0,05 dan nilai signifikansi sesudah krisis 0,029 0,05. Maka dapat disimpulkan bahwa data nilai 
Zulaikah, et al/Jurnal Ekonomi Syariah Teori dan Terapan Vol. 3 No. 11 November 2016: 900-914; PERBANDINGAN FINANCIAL DISTRESS BANK SYARIAH DI INDONESIA DAN BANK ISLAM DI MALAYSIA SEBELUM DAN SESUDAH KRISIS GLOBAL 2008 MENGGUNAKAN MODEL ALTMAN Z-SCORE

Z-Score sebelum krisis varian sama. Sedangkan sesudah krisis memiliki varians yang berbeda karena memiliki nilai signifikansi kurang dari 0,05. Sehingga untuk sesudah krisis harus menggunakan uji beda Independent Sample Kolmogorov Smirnov Z-Test.

\section{Uji Hipotesis}

Pengujian hipotesis dengan mannwhitney menggunakan tingkat signifikansi $5 \%(0,05)$. Apabila hasil perhitungan mannwhitney menunjukkan nilai sig. lebih dari atau sama dengan tingkat signifikansi $(0,05)$, maka Ho diterima $(\mu 1=\mu 2)$, yang berarti tidak terdapat perbedaan yang signifikan. Apabila hasil perhitungan mann-whitney menunjukkan nilai sig. kurang dari tingkat signifikansi $(0,05)$, maka $\mathrm{H}_{0}$ ditolak dan $\mathrm{H}_{1}$ diterima $\left(\mu 1 \neq \mu_{2}\right)$, yang berarti terdapat perbedaan yang signifikan.

Tabel 4.

Hasil Uji Hipotesis Mann-Whitney

\begin{tabular}{|l|c|c|c|}
\hline & Sig. & $\begin{array}{c}\text { Keputusan } \\
\mathrm{H}_{\circ}\end{array}$ & Simpulan \\
\hline $\begin{array}{l}\text { Sebelum } \\
\text { Krisis }\end{array}$ & 0,005 & $\mathrm{H}_{\circ}$ ditolak & $\begin{array}{c}\text { Terdapat } \\
\text { perbeda } \\
\text { an yang } \\
\text { signifikan }\end{array}$ \\
\hline $\begin{array}{l}\text { Sesudah } \\
\text { Krisis }\end{array}$ & 0,002 & $\mathrm{H}_{\circ}$ ditolak & $\begin{array}{l}\text { Terdapat } \\
\text { perbeda } \\
\text { an yang } \\
\text { signifikan }\end{array}$ \\
\hline
\end{tabular}

Sumber : Hasil Penelitian, 2016 (diolah)

Tabel 4. menunjukkan bahwa nilai sig. sebesar 0,005 <0,05. Nilai sig. pada sebelum krisis kurang dari tingkat signifikansinya, sehingga keputusan dari uji hipotesis sebelum krisis bahwa Ho ditolak dan $H_{1}$ diterima. Hasil pengujian ini menunjukkan bahwa terdapat perbedaan yang signifikan antara bank syariah di Indonesia dan Bank Islam di Malaysia sebelum krisis. Hasil pengujian kedua pada sesudah krisis berdasarkan tabel 1.4 menunjukkan bahwa nilai sig. sebesar $0,002<0,05$. Nilai sig. pada sesudah krisis kurang dari tingkat signifikansinya, sehingga keputusan dari uji hipotesis sesudah krisis bahwa $\mathrm{H}_{0}$ ditolak dan $\mathrm{H}_{1}$ diterima. Hasil pengujian ini menunjukkan bahwa terdapat perbedaan yang signifikan antara bank syariah di Indonesia dan Bank Islam di Malaysia sesudah krisis.

\section{Pembahsan}

Perbandingan Financial Distress Bank Syariah di Indonesia dan Bank Islam di Malaysia Sebelum Krisis Global 2008

Hasil pengujian mann-whitney test pada sebelum krisis berdasarkan tabel 1.4 menunjukkan bahwa nilai sig. sebesar $0,005<0,05$. Hasil pengujian ini menunjukkan bahwa terdapat perbedaan yang signifikan antara bank syariah di Indonesia dan Bank Islam di Malaysia sebelum krisis. Hal tersebut serupa dengan penelitan yang telah dilakukan oleh Ekowanti (2011) yang menunjukkan bahwa terdapat perbedaan kinerja keuangan bank syariah secara signifikan maupun rata-rata sebelum dan sesudah krisis global. Perbedaan yang signifikan tersebut dapat dilihat dari hasil nilai Z-score antara bank syariah di Indonesia dan ban Islam di 
Zulaikah, et al/Jurnal Ekonomi Syariah Teori dan Terapan Vol. 3 No. 11 November 2016: 900-914; PERBANDINGAN FINANCIAL DISTRESS BANK SYARIAH DI INDONESIA DAN BANK ISLAM DI MALAYSIA SEBELUM DAN SESUDAH KRISIS GLOBAL 2008 MENGGUNAKAN MODEL ALTMAN Z-SCORE

Malaysia yang berbeda pada periode sebelum krisis.

Tabel 5.

Nilai Altman Z-Score Bank Sampel Periode $2006,2007,2009, \& 2010$

\begin{tabular}{|l|c|c|}
\hline \multirow{2}{*}{} & \multicolumn{2}{|c|}{ Sebelum Krisis } \\
\cline { 2 - 3 } & $\mathbf{2 0 0 6}$ & $\mathbf{2 0 0 7}$ \\
\hline Rata-Rata & 3,36 & 3,34 \\
\hline Indonesia & 6,01 & 5,40 \\
\hline Malaysia & 1,37 & 1,80 \\
\hline
\end{tabular}

Sumber : Hasil Penelitian, 2016 (diolah)

Tabel 5. menunjukkan bahwa bank syariah di Indonesia masuk kategori aman atau tidak bangkrut Z-Score $>$ 2,6. Sedangkan bank Islam di Malaysia masuk kategori grey area 1,1 < Z" < 2,6 yang menunjukkan bahwa tidak dapat dipastikan bank bangkrut atau tidak bangkrut karena terdapat bagian kevangan yang harus lebih diperhatikan sehingga bagian keuangan tersebut harus diperhatikan secara dini. Salah satu penyebab rendahnya nilai Z-Score bank Isalm di Malaysia adalah rata-rata working capital to total asset Malaysia dibawah rata-rata bank syariah di Indonesia.

Tabel 6.

Perbandingan Working Capital to Total

Asset Bank Syariah Indonesia dan Bank Islam Malaysia

\begin{tabular}{|l|c|c|}
\hline & \multicolumn{2}{|c|}{ Sebelum Krisis } \\
\hline & $\mathbf{2 0 0 6}$ & $\mathbf{2 0 0 7}$ \\
\hline Indonesia & 0,78 & 0,73 \\
\hline Malaysia & 0,11 & 0,08 \\
\hline
\end{tabular}

Sumber : Hasil Penelitian, 2016 (diolah)

Tabel 6. menunjukkan bahwa ratarata working capital to total asset bank Islam di Malaysia jauh dibawa rata-rata bank syariah di Indonesia. Hal ini membuktikan bahwa kemampuan untuk menghasilkan kerja modal bersih dari keseluruhan aktiva yang dimiliki bank Islam di Malaysia tidak lebih baik dari kemampuan yang dimiliki olah bank syariah di Indonesia. Sedangkan pada rata-rata earning before interest and taxes to total asset antara bank syariah di Indonesia dan bank Islam di Malaysia memiliki nilai yang hampir sama baik periode sebelum krisis maupun sesudah krisis global.

Tabel 7.

Perbandingan Earning Before Interest And Taxes to Total Asset Bank Syariah Indonesia dan Bank Islam Malaysia

\begin{tabular}{|l|c|c|}
\hline & \multicolumn{2}{|c|}{ Sebelum Krisis } \\
\hline & $\mathbf{2 0 0 6}$ & $\mathbf{2 0 0 7}$ \\
\hline Indonesia & 0,01 & 0,01 \\
\hline Malaysia & 0,01 & 0,02 \\
\hline
\end{tabular}

Sumber : Hasil Penelitian, 2016 (diolah)

Hal yang serupa dengan hasil bank Islam di Malaysia mengalami kesulitan keuangan dapat ditemui pada penelitian yang dilakukan oleh Rahman \& Masngut (2014) pada 17 bank Islam di Malaysia menunjukkan rasio yang lebih rendah dalam membayar gaji karyawan dan cenderung mengalami kesulitan keuangan dalam hal return on asset serta memiliki pinjaman dalam jumlah yang besar. 
Zulaikah, et al/Jurnal Ekonomi Syariah Teori dan Terapan Vol. 3 No. 11 November 2016: 900-914; PERBANDINGAN FINANCIAL DISTRESS BANK SYARIAH DI INDONESIA DAN BANK ISLAM DI MALAYSIA SEBELUM DAN SESUDAH KRISIS GLOBAL 2008 MENGGUNAKAN MODEL ALTMAN Z-SCORE

Perbandingan Financial Distress Bank syariah di Indonesia dan Bank Islam di Malaysia Sesudah Krisis Global 2008

Hasil pengujian Mann-Whitney pada sesudah krisis berdasarkan tabel 1.4 menunjukkan bahwa nilai sig. sebesar $0,002<0,05$. Nilai sig. pada sesudah krisis kurang dari tingkat signifikansinya, sehingga keputusan dari uji hipotesis sesudah krisis bahwa $\mathrm{H}_{0}$ ditolak dan $\mathrm{H}_{1}$ diterima. Hasil pengujian ini menunjukkan bahwa terdapat perbedaan yang signifikan atas financial distress bank syariah di Indonesia dan Bank Islam di Malaysia sesudah krisis global 2008. Hasil ini menunjukkan hasil yang sama dengan periode sebelum krisis. Penelitian ini serupa dengan penelitian yang dilakukan oleh Ardiyana (2011) yang meneliti perbandingan Bank Mandiri dan Bank Syariah Mandiri menggunakan rasio CAMEL. Uji beda mneunjukkan bahwa terdapat perbedaan yang signifikan pada rasio CAR, ROA, dan LDR.

Perbedaan yang signifikan tersebut dapat dilihat dari hasil nilai Z-score antara bank syariah di Indonesia dan bank Islam di Malaysia yang berbeda pada periode sesudah krisis. Perbedaan tersebut dapat dilihat dari perbandingan rata-rata retained earning to total asset antara bank syariah di Indonesia dan bank Islam di Malaysia.

Tabel 8.

Perbandingan Rata-Rata Retained Earning to Total Asset Bank Syariah di Indonesia dan Bank Islam di Malaysia

\begin{tabular}{|l|c|c|}
\hline \multirow{2}{*}{ Nama Bank } & \multicolumn{2}{|c|}{ Sesudah Krisis } \\
\cline { 2 - 3 } & $\mathbf{2 0 0 9}$ & $\mathbf{2 0 1 0}$ \\
\hline Indonesia & 0,03 & 0,03 \\
\hline Malaysia & 0,13 & 0,12 \\
\hline
\end{tabular}

Sumber : Hasil Penelitian, 2016 (diolah)

Selain unggul pada rasio retained earning to total asset, bank Islam di Malaysia juga unggul atau memiliki presentase yang lebih baik dari bank syariah di Indonesia pada rasio book value of equity to total liability. Rasio book value of equity to total liability yang bernilai positif akan cenderung menghadapi financial distress karena itu artinya terdapat jumlah hutang yang harus dibayarkan baik jangka pendek maupun jangka panjang, sebaliknya jika nilainya mendekati negatif maka akan terhindar financial ditress (Nugroho, 2012).

Tabel 9.

Perbandingan Rata-Rata Book Value Of

Equity to Total Liablity Bank Syariah di Indonesia dan Bank Islam di Malaysia

\begin{tabular}{|l|c|c|}
\hline \multirow{2}{*}{ Nama Bank } & \multicolumn{2}{|c|}{ Sesudah Krisis } \\
\cline { 2 - 3 } & $\mathbf{2 0 0 9}$ & $\mathbf{2 0 1 0}$ \\
\hline Indonesia & 0,34 & 0,38 \\
\hline Malaysia & 0.19 & 0.18 \\
\hline
\end{tabular}

Sumber : Hasil Penelitian, 2016 (diolah)

Hasil yang menunjukkan bank syariah di Indonesia memiliki kerentanan yang rendah terhadap financial distress serupa dengan penelitian yang dilakukan oleh Widihadnanto (2015) yang meneliti prediksi financial distress bank syariah dan bank konvensional di Indonesia periode 2011-2014, hasil penelitiannya adalah nilai bankometer seluruh bank syrariah diatas cut-off value $>70$. 
Zulaikah, et al/Jurnal Ekonomi Syariah Teori dan Terapan Vol. 3 No. 11 November 2016: 900-914; PERBANDINGAN FINANCIAL DISTRESS BANK SYARIAH DI INDONESIA DAN BANK ISLAM DI MALAYSIA SEBELUM DAN SESUDAH KRISIS GLOBAL 2008 MENGGUNAKAN MODEL ALTMAN Z-SCORE

Kesulitan keuangan atau financial distress yang dialami oleh bank Islam di Malaysia merupakan bagian dari beberapa faktor yang dapat mempengaruhi. Salah satunya salah satunya adalah kinerja dari pihak perbankan yang mengelola keuangan. Sehingga memberikan dampak negatif. Semua aspek kehidupan pasti akan mengalami kesulitan dalam baik kecil maupun besar, baik individu maupun organisasi atau suatu badan, salah satunya adalah lembaga keuangan perbankan.

Hal tersebut sesuai dengan AlQur'an pada surat Al'Anbiya' ayat 35 :

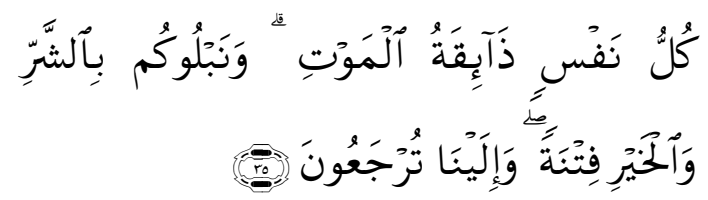

Artinya: Tiap-tiap yang berjiwa akan merasakan mati. Kami akan menguji kamu dengan keburukan dan kebaikan sebagai cobaan (yang sebenar-benarnya). Dan hanya kepada kamilah kamu dikembalikan.

Ayat tersebut menjelaskan bahwa semua makhluk yang ada di bumi akan mengalami kesulitan, baik individu, organisasi, maupun lembaga seperti perbankan. Ujian atau cobaan yang diberikan oleh Allah dapat berbagai macam, salah satunya adalah kesulitan kondisi keungan atau financial distress. Namun hal tersebut dapat diatasi atau diselesaikan dengan strategi yang bijak dari pihak perbankan supaya tidak memberikan dampak terlalu buruk. Sehingga dengan metode Altman Z-Score yang digunakan dapat mengetahui nilai z dan dapat diantisipasi sedini mungkin (early warning system) supaya tidak terjadi kebangkrutan. Dampak kebnagkrutan bank yang dapat menyebabkan pengangguran karyawan, dampak buruknya adalah meningkatkan kemiskinan.

\section{v. SIMPULAN}

Berdasarkan analisis data dan pembahasan yang telah dilakukan pada bab sebelumnya, maka kesimpulan dalam penelitian ini adalah tedapat perbedaan yang signifikan atas prediksi financial distress bank syariah di Indonesia dan bank Islam di Malaysia sebelum dan sesudah krisis global 2008. Penelitian ini menunjukkan bahwa bank syariah di Indonesia lebih baik dalam hal prediksi financial distress dibandingkan bank Islam di Malaysia. Hal ini membuktikan bahwa kinerja bank syariah di Indonesia tidak tertinggal jauh dibandingkan bank Islam di Malaysia yang merupakan negara pendiri bank syariah. Bank syariah di Indonesia mampu menjalankan fungsinya dengan baik sebagai sumber utama pendanaan bagi para pelaku ekonomi ketika terjadi krisis. Maka dari itu, kinerja bank syariah di Indonesia yang baik dapat bersaing dengan bank syariah lainnya dalam menghadapi persaingan global seiring dengan perkembangan bank syariah di berbagai negara di dunia.

Saran yang dapat direkomendasikan setelah melakukan penelitian financial distress bank syariah 
Zulaikah, et al/Jurnal Ekonomi Syariah Teori dan Terapan Vol. 3 No. 11 November 2016: 900-914; PERBANDINGAN FINANCIAL DISTRESS BANK SYARIAH DI INDONESIA DAN BANK ISLAM DI MALAYSIA SEBELUM DAN SESUDAH KRISIS GLOBAL 2008 MENGGUNAKAN MODEL ALTMAN Z-SCORE

Indonesia dan bank Islam Malaysia sebelum dan sesudah krisis global 2008 adalah sebagai berikut :

1. Bagi pihak perbankan, berdasarkan hasil penelitian ini disarankan kepada pihak perbankan Islam di Malaysia untuk melakukan perbaikan kinerja keuangannya terutama pada rasio working capital to total asset dengan cara meningkatkan aset likuid sehingga dapat meningkatkan modal kerja bersih bank dari keseluruhan aset yang dimiliki. Sebab dengan nilai rasio tersebut yang rendah, bank Islam di Malaysia masuk dalam grey area yang tidak dapat dipastikan bangkrut atau tidak bangkrut. Tindakan secara dini yang dilakukan diharapkan dapat mencegah bank tersebut aman dari kebangkrutan. Sedangkan untuk perbankan syariah di Indonesia dapat memperbaiki rasio retained earning to total asset dengan cara meningkatkan laba ditahan untuk mengimbangi jumlah aset, earning before interest and taxes to total asset dengan cara meningkatkan laba sebelum pembayaran pajak dan zakat dari modal yang diinvestasikan dalam keseluruhan aset yang dimilikinya, dan book value of equity to total liability dengan cara mengurangi jumlah hutang sehingga beban hutang yang harus dibayarkan tidak terlampau besar sehingga terhindar dari risiko financial distress. Peningkatan rasio tersebut dapat menjamin ketahanan kevangan perbankan syariah di Indonesia ketika terjadinya krisis sehingga tidak mengalami financial distress yang berujung pada sebuah kebangkrutan.

2. Prediksi financial distress tidak hanya dapat diukur menggunakan metode Altman Z-Score, tetapi dapat dikembangkan dengan model Grover, Springate, Zmijewski, dan Bankometer. Sehingga untuk peneliti selanjutnya dapat memprediksi financial distress dengan memodifikasi berbagai metode. Selain itu, peneliti selanjutnya diharapkan untuk menambahkan periode dan sampel penelitian untuk memperkuat hasil prediksi financial distress. Hingga saat ini masih jarang penelitian tentang perbandingan financial distress antarnegara, kebanyakan penelitian hanya membandingkan bank syariah dan bank konvensional dalam satu negara atau membandingkan dengan dua alat dalam satu sampel bank. Sehingga untuk peneliti selanjutnya dapat membandingkan bank syariah berbagai negara di dunia sehingga dapat diketahui seberapa jauh kinerja bank syariah antarnegara dalam hal ketahanan keuangan di era persaingan global.

\section{DAFTAR PUSTAKA}

Altman, Edward I. \& Editch Hotchkiss. 2006. Corporate Financial Distress and 
Zulaikah, et al/Jurnal Ekonomi Syariah Teori dan Terapan Vol. 3 No. 11 November 2016: 900-914; PERBANDINGAN FINANCIAL DISTRESS BANK SYARIAH DI INDONESIA DAN BANK ISLAM DI MALAYSIA SEBELUM DAN SESUDAH KRISIS GLOBAL 2008 MENGGUNAKAN MODEL ALTMAN Z-SCORE

Bankruptcy. Third Edition. John Wiley \& Sons, Inc. : New Jersey

Anshori, Muslich \& Iswati. 2009. Metodologi Penelitian Kuantitatif. Surabaya: Pusat Penerbitan dan Percetakan Unair (AUP).

Antonio, Muhammad. 2001. Bank Syariah : Dari Teori ke Praktik. Jakarta: Gema Insani.

Ardiyana, Marissa. 2011. Analisis Perbandingan Kinerja Keuangan Bank Syariah dan Bank Konvensional Sebelum, Selama, dan Sesudah Krisis Global 2008 dengan Metode CAMEL. Semarang Fakultas Ekonomi dan Bisnis Universitas Diponegoro.

Awang, Abdul Aziz. Tanpa tahun. Krisis Ekonomi Malaysia : Punca, Implikasi dan Langkah Penyelesaian.

Bank Indonesia. 2009. Outlook Ekonomi Indonesia 2009 - 2014, Edisi Januari 2009.

Bank Negara Malaysia. 2008. Islamic Banking System : Statement of Assets. (Online), (http://bnm.co.id, diakses 15 Desember 2015)

Brigham, E.F. \& JF Houston. 2006. DasaDasar Manajemen Keuangan. Edisi 10. Jakarta: PT. Salemba Empat.

Ekowanti. 2011. Analisis Perbandingan Kinerja Kevangan Perbankan Syariah Sebelum dan Pasca Krisis Global Tahun 2008. Skripsi tidak diterbitkan. Semarang Fakultas Syari'ah Institut Agama Islam Negeri Walisongo.
Emery, Dauglas R \& Finnerty. 1997. Corporate Financial Management. Prentice Hall Books.

Endri. 2009. Prediksi Kebangkrutan Bank untuk Menghadapi dan Mengelola Perubahan Lingkungan Bisnis: Analisis Model Altman Z-Score. Perbanas Quaterly Review. Vol 2. No 1. Maret 2009.

Erari, Anita dkk. 2013. Financial Performance Analysis of PT. Bank Papua : Application of Cael, Z-Score and Bankometer. IOSR Journal of Business and Managemen. 5 (7) : 8.

Hanafi, Mamduh. 2005. Manajemen Keuangan Edisi. Yogyakarta : BPFE.

Husnan, Suad. 1985. Manajemen Kevangan Teori dan Penerapan (Keputusan Jangka Pendek). Yogyakarta: BPPE.

International Financial Services Board, Islamic Finance and Global Financial Stability (Jeddah: Islamic Development Bank, 2010), 1-77.

Kristanti, Farida Titik. 2014. Prediksi Kebangkrutan Bank-Bank yang Terdaftar di Bura Efek Indonesia. Jurnal Keuangan dan Perbankan. 18 (1) : 130. Mishkin, Frederic S.2010. Over The Cliff: From The Subprime To The Global Financial Crisis. Working Paper 16609. National Bureau Of Economic Research.

Moechidie, dkk. 2012. Gerbang Pintar Pasar Modal : Edisi Pertama. Jakarta : PT Jembatan Capital Media. 
Zulaikah, et al/Jurnal Ekonomi Syariah Teori dan Terapan Vol. 3 No. 11 November 2016: 900-914; PERBANDINGAN FINANCIAL DISTRESS BANK SYARIAH DI INDONESIA DAN BANK ISLAM DI MALAYSIA SEBELUM DAN SESUDAH KRISIS GLOBAL 2008 MENGGUNAKAN MODEL ALTMAN Z-SCORE

Munawir, S. 2002. Analisis Laporan Keuangan. Edisi 4. Jakarta : Liberty.

Nugroho, Mokhamad labal Dwi. 2012.

Anlisis Prediksi Financial Distress dengan Menggunakan Model Altman Z-Score Modifikasi 1995. Skripsi. Universitas Diponegoro.

Otoritas Jasa Keuangan. 2008. Statistik Perbankan Indonesia 2008, (Online), (http://ojk.co.id, diakses 10 Januari 2016)

Plat, H. \& Plat, M.B. 2002. Predicting Financial Distress. Journal of Financial Service Professional. 56 (3) : 12.

Prihanthini, Ni Made \& Sari. 2013. Analisis Prediksi Kebangkrutan dengan Model Grover, Altman Z-Score, Springate dan Zmijewski pada Perusahaan Food and Beverage di BEl. E-Jurnal AKuntansi Universitas Udayana. 5 (3) : 547.

Rahman, Rashidah \& Masngut. 2014. The Use of CAMELS "in Detecting Financial Distress of Islamic Bank in Malaysia. The Journal of Applied Bussiness Research. $30(2): 445$.

Ramadhani, Ayu Suci \& Lukviarman. 2009.

Perbandingan Analisis Prediksi Kebangkrutan Menggunakan Model Altman Pertama, Altman Revisi, dan Altman Modifikasi dengan Ukuran dan Umur Perusahaan Sebagai Variabel Penjelas (Studi Pada Perusahaan Manufaktur yang Terdaftar di Bursa Efek Indonesia). Jurnal Siasat Bisnis. 13 (1) : 15.

Riyanto, Bambang. 1995. Dasar - Dasar Pembelanjaan Perusahaan.

Yogyakarta : BPFE - UGM.
Santoso, Singgih. 2013. Menguasai SPSS 21 di Era Informasi. Jakarta: PT Elex Media Kamputindo.

Sharma, N. M. (2013). Altman Model and Financial Soundness of Indian Banks. International Journal of Accounting and Finance, 55-60.

Sudarsono, Heri. 2009. Dampak Krisis Kevangan Global terhadap Perbankan di Indonesia :Perbankdingan antara Bank Konvensional dan Bank Syariah, III (1) : 12 .

Supranto. 2009. Statistik Teori dan Aplikasi, Jilid 2. Edisi 7. Jakarta : Erlangga.

Widihadnanto, Faris. 2015. Perbandingan Prediksi Financial Distress Pada Bank Syariah dan Bank Konvensional di Indonesia Menggunakan Model Bankometer. Surabaya Fakultas Ekonomi dan Bisnis Universitas Airlangga. 